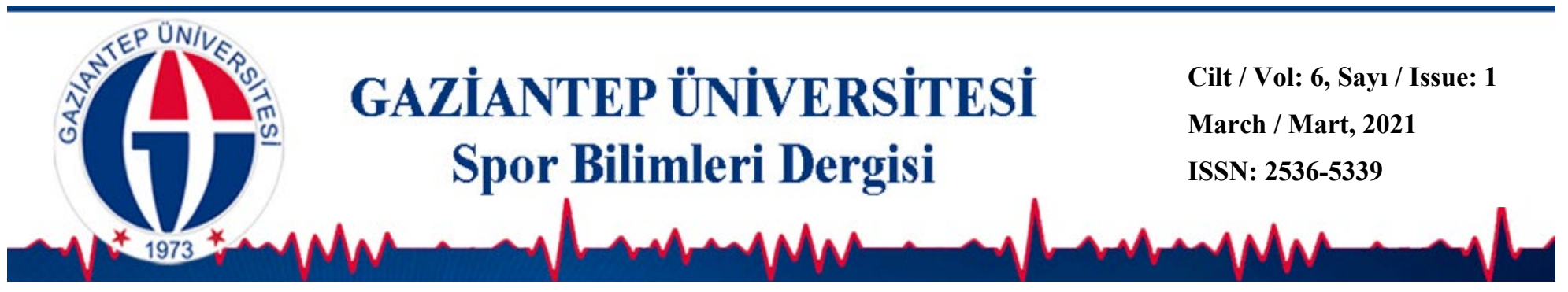

\title{
Elit Seviyedeki Bireysel Kadın Sporcuların Duygusal Zekâ Düzeylerinin İncelenmesi
}

\author{
Demet ÖZTÜRK ÇELIK ${ }^{1 * \text { (ID }}$ \\ Osman YILMAZ1 ${ }^{10}$ \\ İbrahim ŞAHIN ${ }^{2}$ (I) \\ Mehmet BESLER ${ }^{3}$ (D) \\ ${ }^{1}$ Osmaniye Korkut Ata Üniversitesi Beden Eğitimi ve Spor Yüksekokulu, OSMANIYE \\ ${ }^{2}$ Yalova Üniversitesi Spor Bilimleri Fakültesi, YALOVA \\ ${ }^{3}$ Dumlupınar Üniversitesi Spor Bilimleri Fakültesi, KÜTAHYA
}

\section{DOI: $10.31680 /$ gaunjss.881611}

Orijinal Makale / Original Article

Geliş Tarihi / Received:16.02.2021
Kabul Tarihi / Accepted: 18.03.2021
Yayın Tarihi / Published: 22.03.2021

\section{Öz}

Duygusal zekâ bireyin kendini tanımasıyla birlikte başka insanlarla iletişim kurması ve bu iletişim sonucunda oluşan duyguları tanıması açısından insan hayatında önemli rol oynar. Sporcuların hayatında büyük bir öneme sahip olan duygular, fark edilmeli ve yönlendirilmelidir. Duygusal zekâ bu bağlamda büyük bir öneme sahiptir. Araştırmanın amacı elit seviyedeki güreş ve atletizm branşlarındaki kadın sporcuların duygusal zekâ seviyelerini farklı değişkenler açısından incelemektir. Araştırmanın örneklemi, elit düzeyde kadın atletizm ve güreş takımlarında ve milli takımlarda halen aktif olarak görev alan 125 (77 atletizm ve 48 güreş) kadın sporcudan oluşmuştur. Çalışmada araştırmacı tarafından belirlenen kişsisel bilgi formu ve sporcuların duygusal zekâ seviyelerini belirlemek için Lane ve ark., (2009) tarafından geliştirilen ve Türkçe uyarlaması Adiloğulları ve Görgülü (2015) tarafından yapılan Sporda Duygusal Zekâ ölçeği kullanılmıştır. Araş̧ırmanın bulgularına göre atletizm ve güreş branşlarında elit seviyede mücadele eden kadın sporcuların uluslararası derece değişkeninde göre kendi duygularını değerlendirme alt boyutunda anlamlı farklılık olduğu saptanmıştı $(p<.05)$. Yaş değişkenine incelendiğinde duyguların kullanımı ve duyguları düzenleme alt boyutlarında ise anlamlı farklılık olduğu tespit edilmiştir $(p<.05)$. Farkın 23 ve üzeri yaş grubunda olan sporculardan kaynaklandığı görülmüştür. Duygusal zekâ genel ortalama, kendi duygularını değerlendirme, başkalarının duygularını değerlendirme, sosyal beceriler alt boyutlarında ise yaş değişkenine göre gruplar arasında istatiksel açıdan farka rastlanmamışıı ( $p>.05)$. Branş değişkenine göre ise duygusal zekâ puanlarında herhangi bir farka rastlanmamıştır $(p>.05)$. Sonuç olarak elit düzeydeki sporcularda duygusal zekânın yaşla birlikte arttığı ve üst düzey performans gerektiren müsabakalarda başarı gösteren sporcuların daha yüksek duygusal zekâ düzeyine sahip olduğu ve duygusal zekanın performansın belirleyicilerinden biri olabileceği düşünülebilir.

Anahtar Kelimeler: Duygusal Zekâ, Atletizm, Güreş

\footnotetext{
* Sorumlu Yazar: Demet ÖZTÜRK ÇELİK
}

e-mail: demetozturk@osmaniye.edu.tr 


\title{
An Assessment of Emotional Intelligence Levels of Individual Elite Female Athletes
}

\begin{abstract}
Emotional intelligence plays an important role in the life of a person who is to communicate with other people and recognize the emotions in this communication, together with the individual's self-knowledge. Emotional intelligence together with individual self-awareness plays an important role in terms of communicating with others and recognizing the emotions resulting from such communication. Emotions, which are of great importance in the lives of athletes, should be recognized and guided. Emotional intelligence is of great importance in this context. The aim of the study is to examine the emotional intelligence levels of the female athletes in the branches of elite wrestling and athletic by reference to different variables. The sample of study was obtained from 125 (77 athletics and 48 wrestling) female athletes currently active in elite level women's athletics and wrestling teams and national teams. In the study, a personal information form produced by the researcher, along with the Emotional Intelligence in Sports scale developed by Lane et al., (2009) and adapted into Turkish by Adiloğulları and Görgülü (2015), were used to determine the emotional intelligence levels of the athletes. According to findings of the study, when examining the variable of the international rating sub-dimension of female athletes competing in athletics and wrestling branches at the elite level, it was found that the use of emotions was significant $(p<.05)$. It was observed that the difference is due to athletes 23 and above. No statistically significant differences were found between the groups according to the age variable in emotional intelligence general average, evaluating one's own emotions, evaluating others emotions and social skills sub-dimensions ( $p>.05)$. According to the branch variable, no difference was found in emotional intelligence scores ( $p>05)$. In conclusion, it can be inferred that emotional intelligence increases with age in elite athletes, that athletes who are successful in achieving high level performance have higher of emotional intelligence, and that emotional intelligence may be one of the determinants of performance. It has consisted of researchers and athletes. It the study according to the variable, in the age group in comparing their own emotions and feelings.
\end{abstract}

Keywords: Emotional Intelligence, Athleticism, Wrestling

\section{Giriş}

Duygusal zekâ, bireyin kendi duyguları ile birlikte diğer bireylerin duygularını takip etme, bu duygular arası ayrımı yapabilme ve ayrıca bilgiyi düşüncelerine ve davranışlarına rehberlik edecek şekilde kullanabilme becerisini içeren bir sosyal zekâ türüdür (Ayan ve ark., 2017; Mayer ve Salovey, 1993; Meyer ve Fletcher, 2007). Bu kavram ilk olarak 1980'lerde ortaya çıkmış ve 1990'larda Goleman (1995) tarafından bireylerin sosyal hayatlarında ve başka bireyler ile iletişimlerinde başarıyı yakalayabilmeleri için zeka seviyesi (IQ) kadar önemli bir unsur olduğu vurgulanmıştır.

Duygusal zekâ bütün yaşam alanlarının yanı sıra birçok insanın yaşamında yeri olan spor alanında ve atletik performans üzerinde etkin bir role sahiptir (Sit ve Lindner, 2005). Sporculardan yüksek seviyede performans beklendiğinde, kaygı ve stres gibi psikolojik etkenlerin oluştuğu görülmektedir (Mellalieu ve ark., 2009). Sporcuların yaşamış olduğu baskı ve stres duyguları, önemli amaçlar hedeflendiğinde daha da yoğun hale gelmektedir (Lazarus, 2000). Buna ilave olarak koyulan hedeflere ulaşma amacının sporcular üzerinde oluşturduğu stres, baskı ve duygu yoğunluğu günlük ve normal yaşamdakinden daha fazla olabilmektedir (Lazarus, 2000). Duygusal zekâ özellikle müsabakanın gerçekleştiği ortamlarda 
sporcuların duyguları kontrol etmesi, kendi ve diğer insanların (antrenör, rakip sporcu, hakem, antrenör, izleyici vb.) duyguları arasındaki farkı anlayabilmesi için önemlidir. Bu farkındalığı kazanan sporcular değişen durumlarda kendi duygularını istenilen seviyede kontrol ederek sportif performanslarına olumlu katkı sağlamaktadırlar (Adiloğulları ve Görgülü, 2015). Bundan dolayı hem bireysel hem de takım sporlarında mücadele eden sporcuların duygusal öğelerin yönetimi spor yaşantılarındaki önemli hususlardan bir tanesi olarak görülmektedir (Jones, 2003; Robazza ve ark., 2004).

Duygular başarılı spor performansına (Jones, 2012; Laborde ve ark., 2013) ve fiziksel aktivite davranışına etki eder (Mohiyeddini ve ark., 2009; Wang, 2011). Duyguların doğası gereği nispeten geçici olduğu konusunda fikir birliği vardır (Lazarus, 2000; Scherer, 2005). Ancak, teoriler aynı zamanda bireyin duygusal eğilimlerini yansıtan daha istikrarlı, kapsayıcı bir düzeyin varlığına da işaret etmişlerdir (Laborde ve ark., 2013; Lazarus, 2000).

Duyguların atletik performans üzerindeki etkisi, duyguları kontrol etmek ve düzenlemek için yöntemler bulmaya çalışan birçok araştırmacının dikkatini çekmiştir (Lane ve ark., 2010). Buna ilave olarak duygu, spor performansı içindeki etkisini daha iyi kavrayabilmek için önemli bir özellik olarak düşünülmektedir (Lazarus, 2000). Duyguların sportif performans üzerindeki önemi giderek artmakla birlikte duyguları anlayabilme ve düzenleyebilme yeterliliği, sportif performansın başarıı sonuçlarının merkezinde önemli rol aldığı belirtilmektedir (Jones, 2003; Lane ve ark., 2012). Bundan dolayı sportif açıdan vurgulanan duygusal zekâ, sporcular için önemli hale gelmiştir. Bu çalışmada, atletizm ve güreş spor branşlarındaki kadın milli sporcuların duygusal zekâ düzeylerinin yaş, branş ve uluslararası derece değişkenleri açısından incelenmesi amaçlanmıştır.

\section{Yöntem}

$\mathrm{Bu}$ araştırma nicel araştırma türlerinden betimsel tarama modeline uygun olarak düzenlenmiştir. Araştırma için önce literatür taraması yapılmış ve bu konudaki araştırmalar gözden geçirilmiştir.

\section{Evren ve Örneklem}

Çalışmanın evrenini, güreş ve atletizm branşlarında milli takımlarda görev yapan kadın sporcular oluşturmaktadır. Araştımanın örneklemini milli takımlarda aktif 
olarak görev yapmakta olan 125 (77 Atletizm ve 48 Güreş) kadın milli sporcu oluşturmuştur. Belirli bir grubun özelliklerini anket yolu ile tespit edildiği için tarama modeli kullanılmıştır (Büyüköztürk ve ark., 2008). Çalışmanın yapılabilmesi için Osmaniye Korkut Ata Üniversitesi Bilimsel Araştırma ve Yayın Etik Kurulu'ndan (E.6645 sayılı) "Etik Kurul Onayı" alınmıştır.

\section{Verilerin Toplanması}

Veriler google form online anket yöntemi ile toplanmıştır. Veriler google form online anket yöntemi ile toplanmıştır. Duygusal Zekâ Envanteri sporcuların duygusal zekâ yeteneklerini ölçmek amacıyla geliştirilmiştir. Schutte ve ark. (1998) geliştirilen duygusal zekâ ölçeği temel alınarak Lane ve ark. (2009) tarafından 19 madde ve 5 boyut olarak sporcular için uyarlanmıştır. Ölçeğin Türkçe uyarlaması Adiloğulları ve Görgülü (2015) tarafından yapılmıştır. Sporcular için uyarlanan bu envanterin alt boyutları; başkalarının duygularını değerlendirme (5 madde; İnsanların yüz ifadelerine bakarak nasıl hissettiklerini söyleyebilirim, başka biri yaşamıyla ilgili önemli bir olayı bana anlattığında bu olayı neredeyse kendim yaşamış gibi hissederim, başka insanların ne hissettiğini sadece onların yüz ifadelerine bakarak anlarım, insanların neden böyle hissettiğini anlamak benim için zordur, insanların kendilerini nasıl hissettiklerini onların ses tonlarını dinleyerek söyleyebilirim) kendi duygularını değerlendirme (3 madde; duygularımı yaşadıkça onların farkında oluyorum, duygularımın neden değiştiğini bilirim, duygularımı yaşadıkça onları kolayca tanırım), duyguları düzenleme (2 madde; duygularım üzerinde kontrole sahibim, beni mutlu edecek aktiviteleri arar bulurum), sosyal beceriler (3 madde; duygularımı başkalarıyla paylaşmak hoşuma gider, başkalarının hoşlanacağı aktiviteleri düzenlerim, diğer insanlara üzgün olduklarında kendilerini daha iyi hissetmeleri için yardım ederim) ve duyguların kullanımı (6 madde; ruh halim değiştiğinde yeni olasılıkları görürüm, olumlu bir duygu yaşadığımda onu nasıl devam ettireceğimi bilirim, olumlu bir duygu durumunda olduğumda problemleri çözmek benim için kolaydır, ruh halim olumlu olduğunda yeni fikirler bulabilirim, duygularımda bir değişme hissettiğimde yeni fikirler bulmaya eğilimliyimdir, engeller karşısında kararılığımı sürdürmek için iyi ruh hallerimi kullanırım)'dır. Ölçek alt boyutlarının Cronbach alfa değerlerinin 0,61 ile 0,85 arasında değiştiği görülmektedir. Ölçeğin genel iç tutarlılık katsayısının ise 0,91 olarak yüksek olduğu görülmektedir. Bu çalışmada ise ölçeğin Cronbach Alpha değeri tüm ölçek için .86 olarak saptanmıştır. 


\section{Verilerin analizi}

Bu araştırmada verilerin analizi için SPSS 21 istatistik programı kullanılmıştır. Sporcuların duygusal zekâ düzeylerinin farklı değişkenlere göre farklılık gösterip göstermediğini belirlemek amacıyla ilk önce verilerin normal dağılım gösterip göstermediğini belirlemek amacıyla Kolmogorov Smirnov testi uygulanmıştır. Verilerin normal dağılım göstermiş olduğu yapılan test sonucu ile belirlendikten sonra iki grup karşılaştırmasında bağımsız örneklem $T$ testi ve ikiden fazla grup karşılaştırmasında ise tek yönlü Anova kullanılmıştır. Farklılığın hangi gruptan kaynaklandığını tespit etmek için Tukey testi kullanılmıştır.

\section{Bulgular}

Tablo 1. Tanımlayıcı İstatistiki Bilgiler

\begin{tabular}{lccc}
\hline Değişkenler & & $\mathbf{N}$ & $\mathbf{\%}$ \\
\hline \multirow{2}{*}{ Branş } & Atletizm & 77 & 61,6 \\
\cline { 2 - 4 } & Güreş & 48 & 38,4 \\
\hline \multirow{2}{*}{ Uluslararası Derece } & Evet & 75 & 60,0 \\
\cline { 2 - 4 } & Hayır & 50 & 40,0 \\
\cline { 2 - 4 } Yaş & $15-18$ Yaş & 46 & 36,8 \\
\cline { 2 - 4 } & $19-22$ Yaş & 48 & 38,4 \\
\cline { 2 - 4 } & 23 ve Üzeri Yaş & 31 & 24,8 \\
\hline
\end{tabular}

Çalışmaya, 125 katılımcının 77'si (\%61,6) Atletizm branşında 48'i (\%38,4) Güreş branşında görev yapan kadın milli sporcular oluşturmakta, milli sporcuların 75’i $(\% 60,0)$ uluslararası dereceye sahipti, sporcuların 48’i $(\% 38,4)$ 19-22 yaş grubundaki sporculardan oluşmaktadır (Tablo 1).

Tablo 2. Elit Seviyedeki Bireysel Kadın Sporcuların Branş Değişkenine Bağlı Duygusal Zekâ Puanlarına Göre T Testi Sonuçları

\begin{tabular}{|c|c|c|c|c|c|}
\hline Duygusal Zekâ & $\begin{array}{c}\mathrm{N} \\
\text { Atletizm/Güreş }\end{array}$ & A.O. & S.S. & $\mathbf{t}$ & $p$ \\
\hline \multirow{2}{*}{$\begin{array}{l}\text { Başkalarının Duygularını } \\
\text { Değerlendirme }\end{array}$} & 77 & 3,40 & ,66 & 1,087 & \multirow{2}{*}{0,279} \\
\hline & 48 & 3,57 & ,96 & 1,182 & \\
\hline \multirow{2}{*}{ Kendi Duygularını Değerlendirme } & 77 & 3,87 & ,72 &,- 077 & \multirow{2}{*}{0,938} \\
\hline & 48 & 3,88 & ,77 &,- 079 & \\
\hline \multirow{2}{*}{ Duyguları Düzenleme } & 77 & 3,68 & ,93 &,- 546 & \multirow{2}{*}{0,586} \\
\hline & 48 & 3,72 & ,97 &,- 552 & \\
\hline \multirow{2}{*}{ Sosyal Beceriler } & 77 & 3,73 & ,81 &,- 523 & \multirow{2}{*}{0,602} \\
\hline & 48 & 3,83 & ,91 &,- 537 & \\
\hline \multirow{2}{*}{ Duyguların Kullanımı } & 77 & 3,82 & ,61 &,- 668 & \multirow{2}{*}{0,505} \\
\hline & 48 & 3,91 & ,77 &,- 703 & \\
\hline \multirow{2}{*}{ Duygusal Zekâ Ortalama } & 77 & 3,75 &, 57 & 149 & \multirow{2}{*}{0,882} \\
\hline & 48 & 3,76 & ,66 & ,154 & \\
\hline
\end{tabular}


Tablo 2'de elit seviyedeki bireysel kadın sporcularının branş değişkeni sonuçlarına göre duygusal zekâ düzeylerine ait $\mathrm{t}$ testi sonuçları verilmektedir. Duygusal zekâ genel ortalama ve tüm alt boyutlarda gruplar arasında istatiksel açıdan anlamlı bir farka rastlanmamıştır ( $p>05)$.

Tablo 3. Elit Seviyedeki Bireysel Kadın Sporcuların Uluslararası Derece Değişkenine Bağlı Duygusal Zekâ Puanlarına Göre T Testi Sonuçları

\begin{tabular}{|c|c|c|c|c|c|}
\hline Duygusal Zekâ & $\begin{array}{c}\mathbf{N} \\
\text { Evet/Hayır }\end{array}$ & A.O. & S.S. & $\mathbf{t}$ & $\mathbf{p}$ \\
\hline Başkalarının Duygularını Değerlendirme & 75 & 3,59 & 77 & 1,892 & 0,061 \\
\hline Kendi Duygularını Değerlendirme & $\begin{array}{l}75 \\
50\end{array}$ & $\begin{array}{l}3,00 \\
3,99 \\
3,71\end{array}$ & $\begin{array}{l}.91 \\
, 78 \\
, 67 \\
\end{array}$ & $\begin{array}{l}2,006 \\
2,134 \\
\end{array}$ & $0,041^{*}$ \\
\hline Duyguları Düzenleme & $\begin{array}{l}75 \\
50\end{array}$ & $\begin{array}{l}3,78 \\
3,67\end{array}$ & $\begin{array}{l}, 93 \\
, 98\end{array}$ & $\begin{array}{l}633 \\
, 626\end{array}$ & 0,528 \\
\hline Sosyal Beceriler & $\begin{array}{l}75 \\
50\end{array}$ & $\begin{array}{l}3,83 \\
3,75\end{array}$ & $\begin{array}{l}.87 \\
, 88\end{array}$ & $\begin{array}{l}, 503 \\
, 501\end{array}$ & 0,616 \\
\hline Duyguların Kullanımı & $\begin{array}{l}75 \\
50\end{array}$ & $\begin{array}{l}3,94 \\
3,77\end{array}$ & $\begin{array}{l}, 71 \\
, 70\end{array}$ & $\begin{array}{l}1,375 \\
1,380\end{array}$ & 0,172 \\
\hline Duygusal Zekâ Ortalama & $\begin{array}{l}75 \\
50\end{array}$ & $\begin{array}{l}3,83 \\
3,64\end{array}$ & $\begin{array}{l}62 \\
61\end{array}$ & $\begin{array}{l}1,736 \\
1,738\end{array}$ & 0,085 \\
\hline
\end{tabular}

Tablo 3' de elit seviyedeki bireysel kadın sporcuların uluslararası derece değişkenine göre duygusal zekâ düzeylerine ait t testi sonuçları verilmektedir. Uluslararası derece değişkenine göre kendi duygularını değerlendirme alt boyutunda gruplar arası istatiksel açıdan anlamlı bir farklıık olduğu görülmüştür $(P<.05)$. Uluslararası derece elde eden sporcuların kendi duygularını değerlendirme alt boyutunda duygusal zekâ düzeylerinin daha yüksek olduğu görülmüştür. Duygusal zekâ genel ortalama, duyguların kullanımı, duyguları düzenleme, başkalarının duygularını değerlendirme ve sosyal beceriler alt boyutlarında gruplar arasında istatiksel açıdan anlamlı bir farka rastlanmamıştır $(P>.05)$. 
Tablo 4. Elit Seviyedeki Bireysel Kadın Sporcuların Yaş Değişkenine Bağlı Duygusal Zekâ Puanlarına Göre Anova Testi Sonuçları $(n=125)$.

\begin{tabular}{|c|c|c|c|c|c|c|c|}
\hline $\begin{array}{c}\text { Duygusal } \\
\text { Zekâ }\end{array}$ & Yaş & $\mathbf{N}$ & A.O. & S.S. & $\mathbf{F}$ & $\mathbf{P}$ & Fark \\
\hline \multirow{3}{*}{$\begin{array}{l}\text { Başkalarının } \\
\text { Duygularını } \\
\text { Değerlendirme }\end{array}$} & 15-18 Yaş & 46 & 3,66 & 0,89 & \multirow{3}{*}{,054 } & \multirow{3}{*}{,947 } & \\
\hline & 19-22 Yaş & 48 & 3,50 & 0,74 & & & \\
\hline & 23 ve Üzeri Yaş & 31 & 3,45 & 1,06 & & & \\
\hline \multirow{3}{*}{$\begin{array}{l}\text { Kendi Duygularını } \\
\text { Değerlendirme }\end{array}$} & 15-18 Yaş & 46 & 3,70 & 0,92 & \multirow{3}{*}{2,111} & \multirow{3}{*}{,126 } & \\
\hline & 19-22 Yaş & 48 & 3,94 & 0,95 & & & \\
\hline & 23 ve Üzeri Yaş & 31 & 4,02 & 0,76 & & & \\
\hline \multirow{3}{*}{$\begin{array}{l}\text { Duyguları } \\
\text { Düzenleme }\end{array}$} & 15-18 Yaş & 46 & 3,63 & 1,09 & \multirow{3}{*}{3,480} & \multirow{3}{*}{, $034^{*}$} & \multirow{3}{*}{$3<1$} \\
\hline & 19-22 Yaş & 48 & 3,55 & 1,16 & & & \\
\hline & 23 ve Üzeri Yaş & 31 & 3,68 & 0,81 & & & \\
\hline \multirow{3}{*}{$\begin{array}{l}\text { Sosyal } \\
\text { Beceriler }\end{array}$} & 15-18 Yaş & 46 & 4,04 & 0,76 & \multirow{3}{*}{,056 } & \multirow{3}{*}{,945 } & \\
\hline & 19-22 Yaş & 48 & 3,87 & 0,91 & & & \\
\hline & 23 ve Üzeri Yaş & 31 & 3,62 & 0,86 & & & \\
\hline \multirow{3}{*}{$\begin{array}{l}\text { Duyguların } \\
\text { Kullanımı }\end{array}$} & 15-18 Yaş & 46 & 3,78 & 0,87 & \multirow{3}{*}{4,617} & \multirow{3}{*}{, $012^{*}$} & \multirow{3}{*}{$3<1$} \\
\hline & 19-22 Yaş & 48 & 3,82 & 0,71 & & & \\
\hline & 23 ve Üzeri Yaş & 31 & 3,94 & 0,79 & & & \\
\hline \multirow{3}{*}{$\begin{array}{l}\text { Duygusal Zekâ } \\
\text { Ortalama }\end{array}$} & 15-18 Yaş & 46 & 3,77 & 0,76 & \multirow{3}{*}{2,081} & \multirow{3}{*}{,129 } & \\
\hline & 19-22 Yaş & 48 & 3,74 & 0,60 & & & \\
\hline & 23 ve Üzeri Yaş & 31 & 3,75 & 0,72 & & & \\
\hline
\end{tabular}

Tablo 4' de elit seviyedeki bireysel kadın sporcularının yaş değişkenine göre duygusal zekâ düzeylerine ait $\mathrm{t}$ testi sonuçları verilmektedir. Yaş değişkenine göre duyguların kullanımı ve duyguları düzenleme alt boyutlarında gruplar arasında istatiksel açıdan anlamlı bir farklılık görülmüştür $(p<.05)$. Farkın hangi gruptan kaynaklandığını belirlemek için yapılan Tukey testi sonucunda 23 ve üzeri yaş grubunda olan sporcuların, diğer alt yaş grubunda olan sporculara göre duyguların kullanımı ve duyguları düzenleme alt boyutlarında duygusal zekâ düzeylerinin daha yüksek olduğu görülmüştür. Yaş değişkenine göre duygusal zekâ genel ortalama, kendi duygularını değerlendirme başkalarının duygularını değerlendirme ve sosyal beceriler alt boyutlarında gruplar arasında istatiksel açıdan anlamlı bir farklılık görülmemiştir ( $p>.05)$.

\section{Tartışma ve Sonuç}

Duygusal zekâ bireysel duygusal farklılıkların kapsamlı bir şekilde incelenmesini sağlayan bir yapıdır (Sevdalis ve ark., 2007). Bu yaklaşım hem fiziksel hem de psikolojik yönden bireysel adaptasyonu açıklamak için duyguların akıllıca kullanılmasının zorunlu olduğunu savunmaktadır (Extremera ve ark., 2006). 
Araştırmada, güreş ve atletizm branşlarında elit seviyedeki kadın sporcuların branş değişkenine göre gruplar arasında anlamlı bir farklılığa rastlanmamıştır. Benzer şekilde Erbektaş ve ark. (2017) amatör ve profesyonel futbolcular üzerinde yapmış oldukları çalışmalarında branş değişkeni ve duygusal zekâ arasında anlamlı bir fark olmadığını saptamışlardır. Bahadır ve Adiloğulları (2020) spor yapan üniversite öğrencileri üzerinde yapmış oldukları çalışmalarında sporcuların branş değişkenine göre duygusal zekâ düzeyleri arasında anlamlı bir farklıılk olmadığı sonucunu bulmuşlardır. Yalız (2013) basketbol, futbol, hentbol, voleybol, atletizm, yüzme ve jimnastik branşlarını yapan sporcuların duygusal zekâ düzeyleri arasında anlamlı bir fark olmadığı sonucunu ortaya koymuştur. Yalız (2013) beden eğitimi ve spor öğretmenliği bölümü öğrencileri üzerinde yapmış olduğu çalışmasında branş değişkeni ile duygusal zekâ arasında bir ilişki olmadığı sonucunu bulmuşlardır. Yapılan başka araştırmalarda (Baba, 2012; Kajbafnezhad ve ark., 2011) bireysel ve takım sporcularında duygusal zeka yönünden anlamlı bir farklılaşma olmadığı görülmüştür. Bizim bulgularımızın aksine, Salman ve ark. (2018) elit düzeydeki takım ve bireysel sporcuların duygusal zekâ düzeylerini inceledikleri çalışmada takım sporcularının bireysel sporculara göre daha yüksek duygusal zekâya sahip olduklarını belirtmiştir. Yanar (2017) tenis, squash ve badminton sporcuları üzerinde yapmış olduğu çalışmasında duygusal zekâ ile branş değişkeni arasında anlamlı bir farklılık olduğu sonucunu bulmuştur. Bu farklı sonuçlar araştırma yapılan grup, kültür, bölge vb. gibi konularla ilişkilendirilebilir.

Araştırmada, güreş ve atletizm branşlarında elit seviyedeki kadın sporcuların uluslararası derece değişkenine göre kendi duygularını değerlendirme alt boyutunda uluslararası dereceye sahip olan sporcuların duygusal zekâ düzeylerinin daha yüksek seviyede oldukları belirlenmiştir. Duyguların sportif performansındaki önemi her geçen gün artmakla birlikte oluşan duyguları anlama ve düzenleme eğilimi, başarılı sportif performans sonuçlarının merkezinde yer almakta olduğu belirtilmektedir (Jones, 2003; Lane ve ark., 2012). Laborde ve ark. (2016) yüksek duygusal zekâ düzeyine sahip sporcuların daha başarılı olduğunu ifade etmişlerdir.Salman ve ark. (2018) yılında elit sporcular üzerinde yapmış oldukları çalışmalarında milli olan sporcuların sportif kariyeri değişkenine göre duyguların yönetimi, sosyal beceri alt boyutlarında ve duygusal zekâ genel ortalamasında anlamlı farkııık bulmuşlardır. Uluslararası dereceler elde eden sporcuların kendi duygularını değerlendirme alt boyutunda duygusal zekâ düzeylerinin yüksek çıkması sporcuların yaşanmış 
olaylardan ve durumlardan ders çıkarmaları ve sportif başarıların daha fazla olması gibi faktörlerden kaynaklandığı düşünülebilir.

Araştırmada güreş ve atletizm branşlarında elit seviyedeki kadın sporcuların yaş değişkenine göre duyguların kullanımı ve duygu düzenleme alt boyutlarında 23 ve üzeri yaşında olan sporcuların duygusal zekâ düzeylerinin daha yüksek olduğu görülmüştür. Benzer şekilde Karademir ve ark. (2010) spor bilimleri özel yetenek sınavına tabi olan öğrenciler üzerinde yapmış oldukları çalışmalarında duygusal zekâ ile yaş arasında ilişki olduğunu saptamışlardır. Canbulat (2007) çalışanlar üzerinde yapmış olduğu çalışmasında 21-30, 31-40 ve 41 ve üzeri yaş gruplarının duygusal zekâ düzeylerinin "20 yaş ve altı" grubundan anlamlı olarak daha yüksek olduğu sonucunu bulmuştur. Serdengeçti (2003) futbolcular üzerindende yapmış olduğu çalışmasında 32 yaş ve üzeri grubun duygusal zekâ seviyelerinin 28-31 ve daha küçük yaş gruplarına göre daha fazla olduğu sonucunu bulmuştur. Bizim bulgularımızın aksine Özdenk (2018) spor eğitimi alan üniversite öğrencileri üzerinde yapmış olduğu çalışmasında duygusal zekâ ile yaş değişkeni arasında anlamlı bir farklıık olmadığını saptamıştır. Yanar (2017) tenis, squash ve badminton sporcuları üzerinde yapmış olduğu çalışmasında duygusal zekâ ile yaş değişkeni arasında anlamlı bir fark olmadığı sonucunu bulmuştur. Soylu ve Serin (2017) beden eğitimi öğretmenlerinin yaş değişkenine göre istatistiksel olarak bir fark olmadığını belirtmiştir. Bu farklı sonuçlar araştırma yapılan grup, kültür, bölge vb. gibi konularla ilişkilendirilebilir.

Sonuç olarak bu çalışmada, güreş ve atletizm branşlarında elit seviyedeki kadın sporcuların duygusal zekâ seviyeleri incelenmiştir. Güreş ve atletizm branşlarında elit seviyedeki kadın sporcuların branş değişkenine göre gruplar arasında anlamlı bir farklığa rastlanmamıştır. Uluslararası derece değişkenine göre kendi duygularını değerlendirme alt boyutunda uluslararası başarı elde eden sporcuların duygusal zekâ düzeylerinin daha yüksek olduğu görülmüştür. Yaş değişkenine göre ise duyguların kullanımı ve duygu düzenleme alt boyutlarında 23 ve üzeri yaşında olan sporcuların duygusal zekâ düzeylerinin daha yüksek olduğu görülmüştür. Bu sonuçlara göre sporcuların uluslararası anlamda elde etmiş oldukları başarıların ve yaşla birlikte meydana gelen kişisel farkındalıkların duygusal zekâ seviyelerinde artışa neden olduğu düşünülebilir. Araştırmacılar tarafından duygusal zekâ (Salovey ve Mayer, 1990) ve duygu düzenleme (Thompson, 1994) gibi yetilerin bireysel becerilere ışık tutabileceği belirtilmiştir (Fletcher ve Wagstaff, 2009). 
Duygusal zekânın yetenek temelli kuramsal modelini oluşturan Mayer ve Salovey (1993) duygusal zekânın yaşın ve deneyim ile artıı̆ını dayanan gerçek bir zekâ olduğunu öne sürmektedir (Extremera ve ark., 2006; Kafetsios, 2004). Bireyin kendisiyle ilgili farkındalığı insanların duygusal zekâsının geliştirilebilmesinin ön şartıdır. Bu da insanların yaşlarının ilerlemesi ve buna bağlı olgunlaşmayla birlikte kendilerini daha iyi tanıyabilmesini mümkün kılmaktadır (Goleman, 1995).

Çalışmamızın sonucunda, elit düzeydeki sporcularda duygusal zekânın yaşla birlikte arttığı ve üst düzey performans gerektiren müsabakalarda başarı gösteren sporcuların daha yüksek duygusal zekâ düzeyine sahip olduğu ve duygusal zekanın performansın belirleyicilerinden biri olabileceği düşünülebilir. Bundan sonraki yapılacak çalışmalarda elit düzeydeki takım ve bireysel sporcuların cinsiyet karşılaştırması yapılması ve cinsiyet, performans, duygusal zekâ ilişkisini ortaya koyacak başka çalışmalar bu konu hakkındaki literatüre ışık tutacaktır.

\section{Kaynaklar}

Adiloğulları, İ., ve Görgülü, R. (2015). Sporda Duygusal Zeka Envanteri'nin uyarlama çalışması. Uluslararası Spor Egzersiz ve Antrenman Bilimi Dergisi, 1(2), 8394.

Ayan, S., Soylu, Y., Bozdal, Ö., \& Alincak, F. (2017). Investigation of emotional intelligence level of university students. European Journal of Physical Education Sport Science.

Baba, H. (2012). Beden eğitimi ve spor yüksekokulundaki öğrencilerin kinestetik ve duygusal zekâlarının. İç-dış kontrol odaklarının akademik başarılarına etkisi. (Yüksek Lisans Tezi), Gazi Üniversitesi, Ankara.

Bahadır, G., \& Adiloğulları, İ. (2020). Spor Yapan Üniversite Öğrencilerinde Zihinsel Dayanıklılık ile Duygusal Zekâ Arasındaki İlişkinin İncelenmesi. Uluslararası Spor Egzersiz ve Antrenman Bilimi Dergisi, 6(4), 117-128.

Büyüköztürk, Ş., Kılıç-Çakmak, E., Akgün, Ö., Karadeniz, Ş., \& Demirel, F. (2008). Bilimsel araştırma yöntemleri. Ankara: Pegem A Yayıncılık.

Canbulat, S. (2007). Duygusal zekânın çalışanların iş doyumu üzerindeki etkisinin araştıııması. (Yüksek Lisans Tezi), Gazi Üniversitesi, Ankara. 
Erbektaş, E., Üzüm, H., Özen, G., Arslan, T., Ertan, G., \& Elveren, A. (2017). Amatör Ve Profesyonel Sporcuların Duygusal Zekâlarının Bazı Değişkenlere Göre Incelenmesi. Bolu Abant Izzet Baysal Üniversitesi Sosyal Bilimler Enstitüsü Dergisi, 17(4), 263-274.

Extremera, N., Fernández-Berrocal, P., \& Salovey, P. (2006). Spanish version of the Mayer-Salovey-Caruso Emotional Intelligence Test (MSCEIT). Version 2.0: reliabilities, age and gender differences. Psicothema, 18, 42-48.

Fletcher, D., \& Wagstaff, C. R. D. (2009). Organizational psychology in elite sport: Its emergence, application and future. Psychology of Sport and Exercise, 10(4), 427-434. doi:10.1016/j.psychsport.2009.03.009

Goleman, D. (1995). Emotional Intelligence. New York: Bantam Books.

Jones, M. V. (2003). Controlling Emotions in Sport. The Sport Psychologist, 17(4), 471-486.

Jones, M. V. (2012). Emotion regulation and performance. The Oxford handbook of sport and performance psychology. 154-172. New York: Oxford University Pr.

Kafetsios, K. (2004). Attachment and emotional intelligence abilities across the life course. Personality and Individual Differences, 37(1), 129-145. doi:10.1016/j.paid.2003.08.006

Kajbafnezhad, H., Ahadi, H., Heidarie, A. R., Askari, P., \& Enayati, M. (2011). Difference between team and individual sports with respect to psychological skills, overall emotional intelligence and athletic success motivation in Shiraz city athletes. Journal of Physical Education and Sport, 11(3), 249-254.

Karademir, T., Döşyılmaz, E., Çoban, B., \& Kafkas, M. E. (2010). Beden Eğitimi ve Spor Bölümü Özel Yetenek Sınavına Katılan Öğrencilerde Benlik Saygısı ve Duygusal Zeka. Kastamonu Eğitim Dergisi, 18(2), 653-674.

Laborde, S., Dosseville, F., \& Allen, M. S. (2016). Emotional intelligence in sport and exercise: A systematic review. Scand J Med Sci Sports, 26(8), 862-874. doi:10.1111/sms.12510

Laborde, S., Raab, M., \& Dosseville, F. (2013). Emotions and performance: Valuable insights from the sports domain. Handbook of psychology of emotions (Vol 1): Recent theoretical perspectives and novel empirical findings. 325-357. Hauppauge, New York: Nova Science Publishers. 
Lane, A. M., Beedie, C. J., Jones, M. V., Uphill, M., \& Devonport, T. J. (2012). The BASES expert statement on emotion regulation in sport. J Sports Sci, 30(11), 1189-1195. doi:10.1080/02640414.2012.693621

Lane, A. M., Devonport, T. J., Soos, I., Karsai, I., Leibinger, E., \& Hamar, P. (2010). Emotional intelligence and emotions associated with optimal and dysfunctional athletic performance. Journal of sports science \& medicine, 9(3), 388-392.

Lane, A. M., Meyer, B. B., Devonport, T. J., Davies, K. A., Thelwell, R., Gill, G. S., .. . Weston, N. (2009). Validity of the emotional intelligence scale for use in sport. Journal of sports science \& medicine, 8(2), 289-295.

Lazarus, R. S. (2000). How emotions influence performance in competitive sports. The Sport Psychologist, 14(3), 229-252.

Mayer, J. D., \& Salovey, P. (1993). The intelligence of emotional intelligence. Intelligence, 17(4), 433-442. doi:10.1016/0160-2896(93)90010-3

Mellalieu, S. D., Neil, R., Hanton, S., \& Fletcher, D. (2009). Competition stress in sport performers: Stressors experienced in the competition environment. $J$ Sports Sci, 27(7), 729-744. doi:10.1080/02640410902889834

Meyer, B. B., \& Fletcher, T. B. (2007). Emotional Intelligence: A Theoretical Overview and Implications for Research and Professional Practice in Sport Psychology. Journal of Applied Sport Psychology, 19(1), 1-15. doi:10.1080/10413200601102904

Mohiyeddini, C., Pauli, R., \& Bauer, S. (2009). The role of emotion in bridging the intention-behaviour gap: The case of sports participation. Psychology of Sport and Exercise, 10(2), 226-234. doi:10.1016/j.psychsport.2008.08.005

Özdenk, S. (2018). Spor Eğitimi Alan Üniversite Öğrencilerinin Duygusal Zeka Düzeylerinin İncelenmesi. Electronic Turkish Studies, 13(18).

Robazza, C., Pellizzari, M., \& Hanin, Y. (2004). Emotion self-regulation and athletic performance: An application of the IZOF model. Psychology of Sport and Exercise, 5(4), 379-404. doi:10.1016/S1469-0292(03)00034-7

Salman, M. N., Toros, T., \& Soylu, Y. (2018). Elit Sporcuların Duygusal Zekâ Yönünden Karşılaştırılması: Takım ve Bireysel Sporlar. Electronic Turkish Studies, 13(26).

Salovey, P., \& Mayer, J. D. (1990). Emotional Intelligence. Imagination, cognition and personality, 9(3), 185-211. doi:10.2190/dugg-p24e-52wk-6cdg 
Scherer, K. R. (2005). What are emotions? And how can they be measured?. Social science information, 44(4), 695-729. doi:10.1177/0539018405058216

Schutte, N. S., Malouff, J. M., Hall, L. E., Haggerty, D. J., Cooper, J. T., Golden, C. J., \& Dornheim, L. (1998). Development and validation of a measure of emotional intelligence. Personality and Individual Differences, 25(2), 167-177. doi:10.1016/S0191-8869(98)00001-4

Serdengeçti, C. (2003). I. II. III. Ligdeki profesyonel futbolcuların duygusal zekâ düzeylerinin başarıya etkisi. (Yüksek Lisans Tezi), Selçuk Üniversitesi, Konya.

Sevdalis, N., Petrides, K. V., \& Harvey, N. (2007). Trait emotional intelligence and decision-related emotions. Personality and Individual Differences, 42(7), 13471358. doi:10.1016/j.paid.2006.10.012

Sit, C. H. P., \& Lindner, K. J. (2005). Motivational orientations in youth sport participation: Using Achievement Goal Theory and Reversal Theory. Personality and Individual Differences, 38(3), 605-618. doi:10.1016/j.paid.2004.05.015

Soylu, Y., \& Serin, E. (2017). Investigation of emotional levels of physical education and sports teachers (sample of Aksaray province). Sportif Bakıș: Spor ve Eğitim Bilimleri Dergisi, (1), 1-9.

Thompson, R. A. (1994). Emotion regulation: A theme in search of definition. Monographs of the Society for Research in Child Development, 59(2-3), 2552, 250-283. doi:10.2307/1166137

Wang, X. (2011). The role of anticipated negative emotions and past behavior in individuals' physical activity intentions and behaviors. Psychology of Sport and Exercise, 12(3), 300-305. doi:10.1016/j.psychsport.2010.09.007

Yalız, D. (2013). Anadolu Üniversitesi Beden Eğitimi Ve Spor Öğretmenliği Bölümü Öğrencilerinin Duygusal Zekâ Düzeyleri İncelenmesi. Pamukkale Journal of Sport Sciences, 4(2).

Yanar, N. (2017). Tenis, squash ve badminton sporcularında duygusal zekâ düzeylerinin incelenmesi. (Yüksek lisans tezi), Uludağ Üniversitesi, Bursa. 